\title{
The Limits of Consequentialism: ICTY Conditionality and (Non)Compliance in Post-Milosevic Serbia
}

\author{
Nikolas Milan Rajkovic
}

\begin{abstract}
Since 2000 - the dusk of the Milosevic-era-three successive Serbian governments, the Djindjic, Zivkovic and Kostunica administrations, have amassed an inconsistent and oscillating record of (non)compliance with EU and US conditionality for full cooperation with the International Criminal Tribunal on the Former Yugoslavia (ICTY). How do we explain this changing pattern of compliance and noncompliance by Serbia? This paper contends that international rules and norms which attempt far-reaching institutional and social change, such as ICTY conditionality in Serbia, will likely elicit a historical process that is multidimensional and diachronic, more politically complex than the parsimony suggested by incentives-based, model-driven theorizing. The paper argues for a more contextual and practice-oriented approach to the study of compliance politics; focusing on how material, normative and temporal dimensions interact historically to form particular compliance processes \& outcomes. The empirical section uses inductive process-tracing to make a temporal reconstruction of the process and experience of Serbian (non)compliance with ICTY conditionality during the Kostunica government; focusing on the interaction between three dimensions of compliance politics: (1) strategic calculation; (2) identity \& cultural resonance; and (3) temporality.
\end{abstract}

Keywords: Conditionality, Compliance, Serbia, European Enlargement and International Criminal Tribunal on the Former Yugoslavia (ICTY) 


\section{Introduction $^{1}$}

Since 2000-the dusk of the Milosevic-era in Serbia-three successive Serbian governments, the Djindjic, Zivkovic and Kostunica administrations, have amassed a checkered record of compliance with EU and US conditionality for full cooperation with the International Criminal Tribunal on the Former Yugoslavia (ICTY). The aforementioned governments have addressed ICTY conditions in an inconsistent and oscillating fashion: sometimes complying, regularly stalling and often resisting compliance. More remarkable is the fact that protracted delays and outright resistance have been exercised in the face of - or as some would argue in spite of-EU and NATO membership conditionality as well as US financial assistance and sanctions. How do we explain this changing pattern of compliance and noncompliance by Serbian governments? Why did Serbia sometimes comply, while at other times resist cooperation with the ICTY?

A rational-consequentialist approach frames compliance politics as a matter of getting the incentives and punishment right relative to "domestic adoption costs" (Schimmelfennig and Sedelmeier, 2004 \& 2005; Schimmelfennig et al., 2003). In this way, compliance problems are reduced to the following bargaining model: even when determinate and credible prescriptions are combined with substantial rewards or punishment, the size of

\footnotetext{
${ }^{1}$ I extend my thanks to Professors Friedrich Kratochwil, Michael Keating, Pascal Vennesson, Nicole Lindstrom, Florian Bieber, Joan DeBardeleben, Stefano Guzzini and Antje Wiener for their comments and suggestions during my research. My further thanks to Anna Sobczak, Andrew Glencross and those which reviewed this article in its earlier drafts.
} 
domestic adoption costs and their distribution among domestic actors are likely to determine whether prescriptions are accepted or rejected (Schimmelfennig \& Sedelmeier, 2004: 674). As a result, incidents of Serbian noncompliance are explained as outcomes where the domestic political costs of complying with prescriptions proved prohibitively high relative to the rewards, or even the sanctions, on offer; with the vice-versa holding true for cases of compliance.

This paper, however, questions the insight of the above model in the case of ICTY conditionality and (non)compliance in Serbia. I argue that the nature of compliance sought, in terms of the quality of the rules and norms prescribed, greatly influences the extent to which a rational-consequentialist approach can explain the politics of compliance with respect to both process and outcome. In particular, I contend that prescribed rules and norms, which attempt far-reaching institutional and social change, such as ICTY conditionality in Serbia, will elicit a historical process that is multidimensional and more politically complex than the parsimony suggested by a rationalist model.

To probe this claim, I perform a temporal reconstruction of the process of Serbian (non)compliance with ICTY conditionality during the Kostunica government (2004 to the spring of 2007). ${ }^{2}$ This period of history, I argue, provides a useful glimpse at how an

\footnotetext{
${ }^{2}$ Owing to the size restriction of the article and the inductive process-tracing employed, a broader survey involving the Djindjic and Zivkovic governments was not possible here. I chose the Kostunica years because they were the most recent and best encapsulated incidents of Serbian compliance and noncompliance. One of the drawbacks with the chosen time period is that it revolved largely around EU incentives and therefore there was relatively little US involvement-which is in contrast to the earlier mentioned governments.
} 
incentives-based, model-driven approach is explanatively constrained when dealing with the problematique of ICTY compliance. Specifically, the approach downplays the importance of normative and temporal aspects, which together with material incentives form the contextual gestalt of the Serbian case. In the alternative, I argue, we need to develop a more contextual way of studying compliance politics beyond the monological limitations of model-driven and rationalist-inspired theorizing; approaches which reveal the unique material, normative and temporal dimensions of compliance politics and practice.

The analysis that follows therefore is structured into four parts. In the first section, I review and critique the rationalist-consequentialist approach which has been the foundation for the study of compliance politics thus far. Next, I present a short outline on how a more contextual approach might develop as an alternative to a rationalist model of inquiry; problematizing key (meta)theoretical and methodological aspects. Subsequently, I use inductive process-tracing to follow the sequential history of ICTY compliance in Serbia during the Kostunica government; focusing on the interaction between three dimensions of compliance politics: (1) strategic calculation; (2) identity and cultural resonance; and (3) temporality. Finally, I summarize the findings of my process-tracing and discuss its implications for our understanding of compliance theory and practice.

\section{Is Compliance merely about getting the Incentives and Punishment Right?}

At first glance, there may appear to be little to puzzle over regarding inconsistent Serbian compliance with ICTY prescriptions. Scholars of Euro-Atlantic enlargement have 
typically proposed the logics of consequentialism and appropriateness (March \& Olsen, $1998 \& 2005)$ as stylized rationalist versus constructivist answers to the puzzle of how and to what extent Euro-Atlantic institutions have promoted domestic change within accession or target states? In this way, the enlargement scholarship can be said to generally cluster around two poles of interpretation. The first pole emphasizes the manipulation of material incentives as crucial for the adoption of Euro-Atlantic norms and rules (Long, 1996; Pridham, 2002; Hughes \& Sasse, 2003; Schimmelfennig et al., 2003; Schimmelfennig \& Sedelmeier, 2004 \& 2005; Kelley, 2004 \& 2005; Schimmelfennig, 2005). The second pole proposes alternatively that normative suasion and/or interaction are salient for changing the substantive beliefs of target leaders and target societies (Ikenberry \& Kupchan, 1990; Johnston, 2001; Manners, 2002; Checkel, 2005; Flockhart, 2006). The former approach however has traveled furthest within the scholarship through force of persistent advocacy, and hence become a kind of 'orthodoxy' for compliance thinking and theorizing. Therefore the aim of what follows is not to provide a sweeping review of the literature as a whole but rather critique the general 'conditionality' approach which has gained sway over the 'mainstream' field.

As noted above, mainstream theory on Euro-Atlantic enlargement is characterized by a rational-consequentialist approach that reduces rule and norm compliance to the following function: faced with the proper incentives and/or punishment, state agents are suppose to engage in cost/benefit calculations that lead them to align domestic policy with international rules and norms (Checkel, 2000: 4). Indeed, many rationalists are likely to protest at such an austere categorization by pointing to their professed 
commitment to bi- or 'multi-causality' and how fuzzy 'variables', such as norms, persuasion or legitimacy, have also been incorporated into research designs. However, the forthright truth, I claim, is that while many rationalists speak loudly about intellectual evenhandedness, in the end their rationalist understanding of human behaviour obstructs-whether expressly or implicitly_any meaningful interpretation of how culture, norms and identity play a significant and constitutive role in the process of EuroAtlantic enlargement; thereby leaving material forces as the a priori and 'dominant' explanatory factor.

Rationalist approaches obfuscate the social in different ways and do so at the levels of theoretical specification and analytical application (Reus-Smit, 2002). What is common to most rationalist scholars is that they acknowledge the importance of 'normative' factors, yet subsequently circumscribe the significance of that concession by delimiting the role of norms and emphasizing exogenous 'material interests' as the real engines of political action. In this way, an artificial and stylized barrier is placed between 'norms' and 'material interests' such that profound appreciation is lost vis-à-vis how 'norms' influence the constitution of actor identities and interests. It is a dichotomy grounded upon the false assumption that 'material incentives' and 'norms' can be characterized as discrete or adversarial 'mechanisms'; which in turn leaves no prospect for any meaningful and practical understanding of how cultural context and time influence the process of enlargement —other than as a 'constraint' or strategic "switchman" a la Weber (Weber, 1948: 280). 
How the dichotomy between incentives and norms is formulated varies from scholar to scholar: some have made the separation explicit by casting essentialized definitions of 'normative influence' and 'material suasion' into discrete and adversarial 'models'; while others have employed a more subterranean approach, stressing the rhetoric of bi- or 'multi-causality' but yet privileging the force of material incentives. The works of Frank Schimmelfennig and Ulrich Sedelmeier (Schimmelfennig \& Sedelmeier, 2004 \& 2005) and Judith G. Kelley (Kelley, 2004 \& 2005) exemplify these two discursive strategies in the rationalist literature. Both contributions advocate the effectiveness of 'conditionality' over variously defined 'socialization mechanisms'; however Schimmelfennig and Sedelmeier employ explicit contending models, while Kelly invokes the language of bicausality. In the end, the noted differences are more a matter of form as opposed to substance as, I argue, their desire to privilege or test one idealized 'variable' over another reveals a profound misunderstanding of how entangled materialism, cultural legitimacy and temporality are in the process of enlargement: 'norms' mattered for more than the 'sweet talk' and rhetorical pressure exerted by Euro-Atlantic officials; 'the Return to Europe' defined how accession states identified with and construed the benefit of the European project as a whole.

In Governance by Conditionality (2004), Schimmelfennig and Sedelmeier discuss EU "rule transfer" to Central and Eastern European accession countries (CEECs) in the runup to the EU's eastern enlargement. The authors characterize this political process as primarily a "bargaining process" of "reinforcement by reward" or "conditionality', whereby international entities, such as the EU, the Council of Europe (CE) and the 
Organization for Security and Cooperation in Europe (OSCE), provide external incentives (e.g. financial assistance, market access, technical expertise and institutional ties) to a target state so as to alter its behaviour and/or policies. Schimmelfennig and Sedelmeier develop the External Incentives Model (EIM) to encapsulate this process, positing that target actors are "strategic utility-maximizers interested in the maximization of their own power and welfare (Schimmelfennig \& Sedelmeier, 2004: 671)." Further, they hold, the main factor conditioning target state 'choice' is how incentives of 'the bargaining structure' affect the "domestic equilibrium" of preferences and bargaining process in domestic society. The central proposition of Schimmelfennig and Sedelmeier's EIM is that a target state adopts external prescriptions if the benefits of incentives exceed the 'domestic adoption costs'. The authors approximate this costbenefit calculation based on the following factors/mechanisms: "(i) the determinacy of conditions, (ii) the size and speed of rewards, (iii) the credibility of threats and promises, and (iv) the size of adoption costs (Schimmelfennig \& Sedelmeier, 2004: 672)."

Alongside the EIM, Schimmelfennig and Sedelmeier consider alternate 'models' of 'behavioural' change informed by approaches such as 'social learning' and 'lessondrawing'. Each model is furnished with contending hypotheses intended to reveal and test noninstrumental 'mechanisms' of compliance. For instance, the general proposition of the 'social learning model' is that: "a state adopts EU rules if it is persuaded of the appropriateness of EU rules (Schimmelfennig \& Sedelmeier, 2004: 675).” However, due to the author's model-driven design, these non-instrumental processes are effectively relegated to the function of 'control mechanisms': to identify whether, in a particular 
context, noninstrumental processes have superseded the 'dominant' logic of strategic bargaining. Hence, in this way, and as Schimmelfennig and Sedelmeier reveal themselves, incentives become privileged in large part because of the manner in which the authors' frame the inquiry, as an essential choice between discrete models of representation:

"These models [i.e. external incentives and social learning] are not necessarily mutually exclusive; they may be partly competing, partly complementary explanations. But we can ask whether there is a dominant model that explains effective rule transfer from the EU to the CEECs. [...] The main finding of this project is that rule transfer from the EU to the CEECs and the variation in its effectiveness are best explained according to the external incentives model and in particular with the credibility of EU conditionality and the domestic costs of rule adoption (Schimmelfennig \& Sedelmeier, 2004: 671)."

In Ethnic Politics in Europe (2005), Judith Kelly entertains-what I claim is—a similar incentives versus socialization dynamic in her study of how the OSCE, the CE and the EU influenced ethnic minority policy in Latvia, Estonia, Slovakia, and Romania; however she articulates her research design in a more subtle and less adversarial manner. Kelley looks at how two distinct "mechanisms" or "institutional strategies" for influencing state behaviour, "normative pressure" and "membership conditionality", were used to shape policy behaviour and implementation in the aforementioned countries. Kelly circumscribes the former 'mechanism' to the sole use of "norms to persuade, shame, or praise actors into changing their policies", while the latter is characterized as "linking institutional membership to the fulfillment" of a policy recommendation (Kelley, 2005: 3). Kelley later blurs this conceptual distinction with the use of caveats such as: "membership conditionality and socialization-based efforts [were] not mutually exclusive" (Kelley, 2004: 428); and the EU and the CE found "membership conditionality...a convenient extension (Kelley, 2004: 429)" to an existing mix of 
normative and diplomatic arguments. However, I claim, these qualifications merely soften the inherent rationalism which guided Kelley's research; despite her adroit use of 'bridge-building' language.

At first glance, Kelley's commitment to 'bi-causality' appears unquestionable. Not only does she profess a synthetic approach but further she insists that her work "...feeds into the debate about the respective role of norms and incentives, and advances beyond the either/or debate between rationalists and constructivists (Kelley, 2005: 8)." Moreover, Kelley advises readers on how "rational-choice scholars focus on behaviour change, while socialization scholars traditionally focus on belief change. With the proper caution, it is nevertheless useful to study both mechanisms in terms of their policy effects (Kelley, 2004: 428)."

However, closer scrutiny of Kelley's analytical frameworks and empirical findings, I argue, reveal a subterranean rationalism which privileges material over normative factors. For instance, absent within Kelley's theoretical discussion is any serious consideration of how social identities (and consequently social norms) influence interest-formation; and this brings Kelley to adopt—whether wittingly or not—-the conventional rationalist view that material interests (desires) stand in priority to social norms (beliefs) (see Wendt, 1999: 34-35). Hardly surprising therefore is her later finding that EU and CE membership conditionality was frequently the "decisive" factor in shaping domestic policy on ethnic issues. In fact, Kelley's subsequent discussion on the practical role of 'norms' revealed an instrumentalist—as opposed to a constitutive-view. This was 
exemplified with her conclusion that if the change in "payoffs' were "large enough"; policy actors were likely to change their policies and even 'rationalize' the change to their constituencies; "even if they [do] not accept the normative argument (Kelley, 2004: 431)." Yet nowhere was it contemplated by Kelley that the very "payoffs' referred to were nested within the broader social lure of a united 'Europe', and that this may have also contributed to the above-described 'calculations' and subsequent 'rationalization' of policy choices. In this way, what was occluded by Kelley was a consideration of the relational and cultural meaning of 'policy compliance' within the framework of 'European' accession; or to paraphrase Marshall Sahlins' argument: how the "material effects" of policy choices ultimately depend upon "their cultural encompassment (Sahlins, 1976: 194).”

\section{Bringing Context 'back-in': Compliance Politics as the Study of Historical Circumstances and Time}

The purpose of the above criticisms however has not been to deny the analytical value of rationalist approaches to compliance politics. To the contrary, rationalist approaches can provide important heuristic insights at particular political junctures; yet the common problem with rationalist theorizing is its tendency to overstate the salience of material incentives and neo-liberal bargaining in particular processes and outcomes. In this way, while conventional rationality and material forces need to be acknowledged as important explanatory factors in specific situations, where brute 'material facts' induce actors into 'cost/benefit' calculus (Checkel, 2001: 556); at the same time, however, what is also 
needed is greater appreciation of how temporal and cultural contingencies make 'rationalist' reasoning practically possible at discrete times and in particular contexts.

This means that the above critique should not be construed as a wholesale rejection of material incentives, as a refutation of this sort flies in the face of rationalist aspects (e.g. rewards and sanctions) which are embedded within cases of compliance politics. Rather, my argument here is that the parsimony of an incentives-based and model-driven explanation, while potentially robust in terms of predicting some outcomes, runs the risk of providing only a partial explanation of political practice in many complex cases. And it is worth emphasizing: complex cases are complex because they involve a multidimensional context and process, exhibiting changing constellations of material, normative and temporal factors. Thus, any claim of profound analysis requires that one explain these various dimensions which make up the contextual gestalt of compliance cases.

Yet, such a stance brings us to an important question: how do we theorize and study context? Moreover, should you? These are profound and difficult issues which are linked inherently to conflicting stances on what constitutes proper scholarly or 'scientific' inquiry in the study of social and political 'reality' — a significant metatheoretical debate beyond the scope of this paper (Beyerchen, 1992/1993; Davis, 2005; Kratochwil, 2000; Kratochwil, 2006; Kratochwil, 2007; Lebow, 2007; Stewart, 1997; Watts, 1997/1998). However, the brief remarks which follow aim to engage with various aspects of this controversy: as I foremost claim that we should analyze 'context' in compliance politics, 
however not as monological theory but rather as a field of practice with variable realizations and meanings across time. With this assertion I attach an important caveat: the goal of this section is not to present a 'contextual theory' of compliance politics or to set out the fine-print of a contextual research programme, instead it is to provide a short outline of how a more contextual approach might develop, touching upon key (meta)theoretical and methodological issues largely silenced by the environs of modeldriven theorizing.

First, a more contextual understanding of compliance politics may require a profound philosophical reorientation at the very outset. To paraphrase the words of R.B.J. Walker: our philosophical premises often prefigure our concepts and theories (Walker, 1989: 178). Therefore, for the contingent logic of practice and context to be brought back into compliance analysis, we need to reconsider the epistemology-centred view of Cartesian science which has been the backbone of modernist social and political thought (Taylor, 1984). In other words, we need to acknowledge the inherent limits of epistemic (universalized) theory in terms of what it can tell us about the sui generis experience of social and political practice. Simply put: for all its parsimony and elegance, we have to problematize deductive theory as practice and begin to appreciate Bourdieu's insight "that practice has a logic which is not that of logic (Bourdieu, 2005: 109)."

The intent however is not to refute the heuristic value of deductive theories or hypotheses, or say that 'anything goes' in the realm of compliance analysis, but rather to emphasize that the practice of compliance politics is both multi-dimensional and diachronical. Such a metatheoretical stance, I claim, becomes important in the analysis 
of complex cases like ICTY conditionality and compliance because of what I call 'thick contexts': multiple means of variable influence (e.g. incentives, normative and identity suasion) interacting in variable time with multiple decision-making dimensions (e.g. problems of interest-formation and identity framing), producing synergistic and nonlinear processes that surpass the monological capacity of model-driven theory (rationalist or constructivist). It bears highlighting that model-driven theory is considerably disadvantaged when studying such multifarious scenarios because of its (1) either/or stance between material and normative structures, (2) desire to ascertain 'primary' mechanisms (Checkel, 2005) and (3) embrace of temporal abstraction (Sewell, 1996).

Profound explanation in 'thick' contexts, I argue, cannot arise via approaches which focus on a single dimension (e.g. incentives) or articulate compliance as consisting of $a$ priori mechanisms producing self-evident outcomes. Rather, they require a type of analysis attentive to the historical conditions which have produced compliance outcomes; an approach that recovers options made unthinkable (Taylor, 1984) by political and social practice; an inquiry which is skeptical of the alleged dichotomy between norm-governed versus strategic behaviour (March \& Olsen, 1998 \& 2005); and finally, a historical stance that questions temporal abstraction, emphasizing instead the force of sequences and events upon political outcomes (Abbott, 1983 \& 1988; Sewell 1996; Sommers, 1996).

How might we implement this revised (meta)theoretical outlook in methodological terms? I propose that so-called process-tracing is the preferred method of inquiry. Generally speaking, process-tracing implies a close, historical study of political processes 
in order to reach a 'thicker' explanation of specific political events. Yet, the mere mention of this method does not resolve the philosophical cleavages (metatheoretical stances) identified above: advocates of process-tracing differ on whether to use the method deductively or inductively. George and Bennett, for instance, define processtracing with a variable-oriented language common to model-driven theorizing, it: "attempts to identify the intervening causal process - the causal chain and mechanismbetween an independent variable (or variables) and the outcome of the dependent variable (George and Bennett, 2005: 206)." Davis, however, approaches process-tracing in a more diachronic manner:

"Characterizing the social world as a collection of cases understood in terms of discrete events or outcomes may lead us to overlook the wealth of historical experiences that are represented in each individual case. Although for some purposes it might make sense to conceive of cases as discrete empirical entities that permit only a single observation for measurement and coding, this is not always true. Rather, for some purposes it makes more sense to think of cases as complex phenomena, each of which comes with a history (Davis, 2005: 175)."

The difference between the two stances is not trivial, and with growing interest in the method I expect a chasm to develop. Why? The difference articulated between Bennett and George vis-à-vis Davis touches upon a large debate located—this time-within the historical sciences on the nature of 'historicity'; or, as E.H. Carr aptly put it, the problematique of "What is History? (Carr, 1961)" For our present purposes we need not plunge into the depths of this important controversy but rather remain cognizant of it with respect to two key points. First, we need to be weary of teleological or "confirmatory" analyses of history intended to support a particular deductive theory or hypothesis (Lustick, 1996; Kratochwil, 2006: 14; see Roberts, 1996). Second, compliance analysis should take temporality more seriously relative to causality, focusing on the very process 
of compliance politics, specifying its contexts across time (Sewell, 1996; Sommers, 1996). In a nutshell, a genuine rethink is in order regarding how sequences and events fundamentally interact with material and normative structures to form particular compliance scenarios. Such reflection brings us to an important point expressed by Pierson: "that any event or process is environed by its temporal location, its place within a sequence of occurrences, and by its interactions with various processes unfolding at different speeds (Pierson, 2004: 172)." In sum, a more temporal orientation towards the study of compliance politics means that history is far from "bunk"; and instead of viewing historical analysis as the valet of causal hypotheses, we need to pay greater attention to how material, normative and 'eventful' dimensions interact and constitute compliance outcomes across time.

\section{Kostunica's ICTY 'Odyssey': A Multidimensional and Diachronic Reconstruction}

In the foregoing section, therefore, I have presented an argument for a contextual approach to the study of compliance politics. In particular, I have attempted to rearticulate compliance theory and practice by questioning some of the (meta)theoretical and methodological postulates that anchor the present-day, rationalist study of compliance politics, such as: the epistemology-centred view of Cartesian science; the theory as practice of the epistemological model; and the primacy of causality over temporality. All these arguments come as first intimations and, indeed, further theoretical elaboration and argumentation will be required. However, as any good lawyer or even mathematician will tell you, argumentation alone cannot bring 'context' to any 
meaningful standing within compliance theorizing, as demonstration also plays some meaningful and persuasive role- "the proof is in the pudding" so the saying goes. Therefore in this section I turn to empirics and process-tracing to address the ultimate question of 'why bother?' Or, more specifically, what analytical difference would a more contextual approach make in the analysis of compliance politics?

The case of ICTY conditionality and compliance in Serbia is a useful opportunity for this purpose. Obviously, a study of Serbia alone can neither prove nor disprove the case for a contextual approach, but it can serve as an initial probe to reveal the potential valueadded. In this vein, the goal here is rather simple: to reveal the history which is 'forgotten' when a rationalist model of compliance 'reality' is relied upon. The remainder of this section, therefore, performs a temporal reconstruction of ICTY compliance in Serbia during the recently expired Kostunica government (2004-2007); starting with the election campaigns that brought it to power in the fall of 2003, and ending with the present-day Mladic crisis.

The method of process-tracing used is expectantly inductive and temporal as opposed deductive and teleological; something atypical for the compliance mainstream which has largely conflated the deductive approach with process-tracing (e.g. Schimmelfennig and Sedelmeier, Kelley). The objective here is to reconstruct in a "Post-Mortem" fashion the sequence of events which played out before, during and after particular extradition crises; endeavouring to uncover how material incentives, identity politics and events interacted in time to constitute compliance processes and outcomes. In this way, three hypotheses 
are considered in a heuristic fashion: (1) Strategic Calculation-target actors engage in cost/benefit calculations that lead them to adopt international prescriptions (Schimmelfennig and Sedelmeier, 2004 \& 2005; Kelley, 2005); (2) Identity and Cultural Resonance-target actors operate in a culture space that defines what is a legitimate policy, action or belief (Barnett, 1999; Wiener, 2004); and (3) Temporality- "the course of history [is] determined by a succession of largely contingent events (Sewell Jr., 1996)." It bears emphasizing: these hypotheses are construed as interacting and nonlinear 'dimensions' rather than as a priori 'mechanisms.' Therefore, the historical narratives which follow do not subsume historical phenomena under a universal 'covering law' of one or another hypothesis, but instead emphasize how and when a particular incentive, identity frame or event became salient in a historical sequence and how it interacted with other dimensions.

In total, the Kostunica government faced three major extradition crises (the Four Generals Crisis; The Feasibility Study Deadline; and the Mladic Crisis), critical junctures that will guide our empirical analysis and be examined in historical sequence. The primary sources used for my historical reconstruction are online news archives: news clippings, bulletins and press releases found in either the Serbian (e.g. B92 News) or foreign (e.g. Reuters; Agence France Presse; New York Times) news media. To supplement this survey of the public record, individual interviews were conducted with former and current Serbian government officials and foreign diplomats in Belgrade. 


\section{a. The Power of Bad Timing: Carla Del Ponte and the Elections of 2003}

The following history of ICTY compliance in Serbia begins with the country's 2003 Presidential and Parliamentary elections, conducted respectively in November and December of that year. The aforesaid campaigns were characterized by a number of electoral issues; however unexpected contingency made ICTY cooperation a dominant one. How? Within weeks of the respective votes, ICTY Chief Prosecutor, Carla Del Ponte, broke an alleged agreement with Serbian authorities ${ }^{3}$ and served public indictments against four Serbian generals (Pavkovic, Lazarevic, Lukic and Djordjevic). The indictments came as a shock to both the Serbian electorate and the ruling DOS (Democratic Opposition of Serbia) coalition, headed by then Prime Minister Zoran Zivkovic. In fact, the shock was so great that, despite its previous extradition of Slobodan Milosevic and its decidedly pro-western stance, the DOS government steadfastly refused to arrest and extradite any of the newly indicted generals.

The effect of the public indictments amounted to a kind of political chemotherapy: while Del Ponte reasserted the ICTY's mandate over the Serbian government in the international sphere, she simultaneously hurt the electoral fortunes of Zivkovic's proWestern and liberal-leaning coalition-the mostly likely domestic allies to secure cooperation with the ICTY. Entering the electoral campaign, the ICTY was highly unpopular: polling data not only suggested that 75 percent of Serbian citizens "did not trust" the $\mathrm{ICTY}^{4}$ but, in addition, 59 percent indicated that they were against

\footnotetext{
${ }^{3}$ Interview with Former Prime Minister Zoran Zivkovic, interview by author, 20 April 2005.

${ }^{4}$ See Centar za politikoloska istrazivanja i javno mneje, Institut Drustvenih Nauka, Stavovi Gradjana o Medunarodnoj Zajednici i Odnosima Srbije i Crne Gore Krajem 2004. Godine (Belgrade: Centar za
} 
cooperation. ${ }^{5}$ The calamitous prospect raised by the indictments was further evidenced by the public appeals made by Zivkovic's coalition partners for international empathy and savvy. DOS Presidential candidate Dragoslav Micunovic implored that: "the indictments had destabilized democratic progress in the country." ${ }^{6}$ Nenad Canak, Social Democrat and Vojvodinian regional leader, was less diplomatic and argued that: "the indictment of the four generals was political timing of an unseen stupidity, which would forestall future steps toward democratization in Serbia."7 Further, as if to confirm that even the "Serbian street" understood the public storm that Del Ponte had instigated, the Serbian daily Politika released a survey on the eve of the Presidential election which revealed that two-thirds of respondents thought the indictments could not have come at a "worse political time." 8

In the end, there were two principal beneficiaries from the above-described meltdown: initially the Serbian Radical Party and later Vojislav Kostunica. The Radicals ran on a Presidential and Parliamentary platform that placed their anti-Hague agenda front and

\footnotetext{
politikoloska istrazivanja i javno mneje, Institut Drustvenih Nauka, 2005) <www.cpijm.org.yu/scharts/Izvestaj1.pdf> (February 11, 2005).

5 'Sednica Saveta za saradnju sa Haskim tribunalom naredne nedelje,'B92 News, 26 October 2003, <www.b92.net/info/vesti/index.php?yyyy=2003\&mm=10\&dd=26\&nav_id=123045\&nav_category=11> (November 29, 2004).

6 'Micunovic: Optuznice destabilizuju demokratski poredak u zemlji,' B92 News, 26 October 2003, <www.b92.net/info/vesti/index.php?yyyy=2003\&mm=10\&dd=26\&nav $\mathrm{id}=123052$ > (November 29, 2004).

7 'Canak: Haska optuznica protiv cetvorice-'nevidjena budalastina,', B92 News, 26 Oct 2003, <www.b92.net/info/vesti/index.php?yyyy=2003\&mm=10\&dd=26\&nav_id=123012\&nav_category=11>, (November 29, 2004).

8 'Anketa: Optuznice stigle u najnezgodnijem trenutku,' B92 News, 3 November 2003, <www.b92.net/info/vesti/index.php?yyyy=2003\&mm=11\&dd=03\&nav_id=123650\&nav_category=64>, (November 29, 2004).
} 
centre ${ }^{9}$ they profited handsomely from this strategy. When the returns came in from the Serbian Presidential Election on November 17, the Radicals emerged the clear winners, taking 46 percent of the vote. ${ }^{10}$ Similarly, the Parliamentary vote on December 28 revealed that the Radicals had again come out on top with 28 percent. The remaining spectrum of democratic parties could fair no better than the high teens: Kostunica's Democratic Party of Serbia (DPS) got 18 percent, Zivkovic's Democratic Party (DP) 13 percent, the liberal economic G17Plus 12 percent, and the Serbian Renewal Movement/New Serbia 8 percent. ${ }^{11}$ In his victory address to the party faithful, the Radical Party deputy leader and Presidential candidate Tomislav Nikolic declared: "this is a clear message from the citizens of Serbia that patriotic forces and the anti-Hague lobby have prevailed."12

But Nikolic and his party were unable to cash-in on their electoral gains. First, the Presidential election failed to garner the minimum number of votes required by law to

\footnotetext{
${ }^{9}$ Article 5 of the Serbian Radical Party's December 2003 election platform: "The Serbian Radical Party will fight with all political means against the destruction of the Serbian national being, as well as against the false accusations and the ostensible guilt of Serbs for the conflicts in the Former Yugoslavia. Serbian Radicals will do everything to show to the Serbian citizens and world public the real, dangerous sense of The Hague Tribunal, to unmask its activities and to give political and every other kind of support to the imprisoned Serbs, especially to the President of the SRS, Vojislav Seselj." "Program Srpske Radikalne Stranke," Velika Srbija (Belgrade: Serbian Radical Party, December 2003). Available in Cyrillic at <www.srs.org.yu/onama/program.php?izbor=onama〉.

10 'Izbori propali, Nikolicu najvise glosova,' B92 News, 16 November 2003, $<$ www.b92.net/info/vesti/index.php?nav category $=11 \& d d=16 \& m m=11 \&$ yyyy $=2003>($ November 29, 2004).

11 'CeSID: Najvise radikali, slede DSS, DS, G17, SPO-NS, SPS,' B92 News, 28 December 2003, <www.b92.net/info/vesti/index.php?nav_category=11\&dd=28\&mm=12\&yyyy=2003 $>($ November 29, 2004).

12 'Nikolic: U Srbiji pobedjuju patrotske snage i antihaski lobi,' B92 News, 17 November 2003, <www.b92.net/info/vesti/index.php?yyyy=2003\&mm=11\&dd=16\&nav_id=124891\&nav_category=11> (November 29, 2004).
} 
validate the result, and hence the outcome was annulled. ${ }^{13}$ Second, while the Radicals attained the highest number of votes in the Parliamentary election, they did not have a parliamentary majority and therefore needed a coalition partner from the democratic block to form a government; something very unlikely considering the country's recent past.

In short, with the Radicals stuck and Zivkovic's DP wounded, the door was open for Kostunica, whose party was the second-highest vote getter, to seize the initiative and form a coalition government. On February 21 2004, after weeks of intense negotiations with the remaining democratic parties, Kostunica formed a minority government consisting of his DPS, the G17Plus party under liberal economist Miroljub Labus, and the Serbian Renewal Movement/New Serbia led both by veteran democracy campaigners Vuk Draskovic and Velimir Ilic. ${ }^{14}$ Yet, the coalition was not without controversy. To secure a parliamentary majority, the incoming coalition had to obtain legislative support from Milosevic's former party, the Socialist Party of Serbia. ${ }^{15}$

What did this new coalition government mean for the future of Serbia-ICTY relations? In a campaign interview given by Kostunica to Serbian broadcaster B92 News on October 23, he gave an indication of what lay ahead in the coming weeks and months:

\footnotetext{
13 'Izbori propali, Nikolicu najvise glasova,' B92 News, 16 November 2003.

14 'Koštunica i zvanično mandatar za sastav Vlade,' B92 News, 21 February 2004, <www. http://www.b92.net/info/vesti/index.php?dd=20\&mm=2\&yyyy=2004> (April 29, 2004).

15 Ibid.
} 
"The justice of The Hague Tribunal is selective and we have to take a different, more aggressive approach; to make it clear that we will cooperate with The Hague, but not in a way where it appears that only one side is responsible for the war. [...] I have one political agenda, and that is the protection of state interests in some national sense, whether its' about the reputation of the country, or in a material way...."16

In sum, Kostunica's skeptical opinion of the ICTY signaled more dysfunctional relations between Serbia and the international community. However, as the rise of the Radicals showed, this was not merely one man's or one party's crusade against the ICTY. AntiHague sentiment was a significant part of the Serbian political landscape, and it commanded votes. To get ICTY cooperation now would require convincing not only the leaders but the led as well. Del Ponte's public and ill-timed hard-line had given impetus to the surging Radical Party and allowed Kostunica to harden rather than soften Serbia's approach to ICTY compliance.

\section{b. $\quad$ Critical Junctures \& the Power of Incentives: The Road to Brussels goes through The Hague}

During the first ten months of Kostunica's premiership (February to December 2004), cooperation between Serbia and the ICTY "amounted to zero," according to then US war crimes envoy Pierre-Richard Prosper. ${ }^{17}$ Prosper's rebuke of Kostunica on December 6, 2004 was not without foundation. First, since Kostunica's coming to power, there had been no arrests of high-ranking indictees such as Generals Mladic, Lukic, Lazarevic,

\footnotetext{
16 'Kostunica: Vlast vodi pogresnu politiku u odnosu na Haski sud,' B92 News, 23 October 2003, <www.b92.net/info/vesti/index.php?yyyy=2003\&mm=10\&dd=23\&nav_id=122844\&nav_category=11> November 29, 2004).

17 'Prosper: Saradnja Beograda na nuli,' B92 News, 6 December 2004, <www.b92.net/info/vesti/index.php?yyyy=2004\&mm=12\&dd=06\&nav id=157289> (December 7, 2004).
} 
Pavkovic and Djordjevic, as well as former Bosnian Serb leader Radovan Karadzic. Moreover, it was common knowledge that three of the abovementioned generals (Lazarevic, Pavkovic and Lukic) were living freely and openly in Serbia despite their indictment by the ICTY. ${ }^{18}$ Second, Kostunica himself seemed to be in no hurry; playing a waiting game of sorts with the Tribunal. In an interview given to B92 News on November 20 2004, Kostunica stated: "We have to cooperate with The Hague, but like with all matters, some things can be done today, some things tomorrow, while others just need more time. $[\ldots]^{, 19}$

International condemnation quickly translated into criticism at home. In the days that followed Prosper's reprimand, both newly-elected Serbian President Boris Tadic and one of Kostunica's coalition partners, Serbia and Montenegro Foreign Minister Vuk Draskovic, expressed their public concern over Kostunica's ICTY policy, or the lack thereof. Tadic emphasized: "without cooperation there is...no entry into the EU, no increase in the standard of living. Our poverty rate will rise, we will have no political stability, so long as we are excluded from the international community...."20 Draskovic stressed that Europe wanted Serbia amongst its ranks and was waiting for Serbia to joint

\footnotetext{
18 'Kostunica guilty for Hague obstruction,' B92 News, 7 December 2004, <www.freerepublic.com/focus/fnews/1297152/posts> (May 25, 2005).

19 'Srbija mora da saradjuje sa Hagom,' B92 News, 20 November 2004, <www.b92.net/info/vesti/index.php?yyyy=2004\&mm=11\&dd=20\&nav_id=156197> (November 21, 2004).

20 'Tadic i Draskovic: U Evropu preko Haga,' B92 News, 9 December 2004, <www.b92.net/info/vesti/index.php?yyyy=2004\&mm=12\&dd=09\&nav id=157512> (December 9, 2004).
} 
it, however Europe's patience was limited and Serbia faced the prospect of "selfisolation." 21

Yet, Kostunica and Serbia were not the sole targets of criticism. The lack of results had also cast scrutiny on the policy of ICTY conditionality itself as well as one of its chief handlers, Carla Del Ponte. In an op-ed piece for the Montenegrin daily Republika on October 16 2004, former US Ambassador to Serbia and Montenegro, William Montgomery, expressed second-thoughts about the practice of ICTY conditionality, with especially harsh words for how Del Ponte had exercised her discretion:

“[...] ...I believe the US Congress' policy that, like in the case of Milosevic's arrest and extradition to The Hague, aid to Serbia is conditional upon further cooperation with The Hague Tribunal has revealed itself to be counterproductive. We are witnesses to how the number of indictees grew and how this type of policy reinvigorated nationalism in Serbia and made the work of democratically elected governments more difficult. [...]

[...] The aggressive and arrogant posture of the Chief Prosecutor, Carla Del Ponte, strengthened nationalist forces and brought into doubt the work of democratic governments. In this way, she made it difficult for any politicians to cooperate with the Tribunal. [...]",22

In sum, Prosper's condemnation, Tadic's and Draskovic's domestic intervention and Montgomery's criticisms of ICTY conditionality itself indicated that perhaps SerbiaICTY relations were coming to a cross-road. If so, the question was: where was the road

\footnotetext{
${ }^{21}$ Ibid.

22 'Karla del Ponte nanosi stetu,' Republika, 16 October 2004, <www.republika.cg.yu/arhiva.phtml?akcija=vijesti\&id=3693 > (October 16, 2004).
} 
headed, to greater stalemate or a watershed? Furthermore, did the international community have any cards to play?

It turned out that the EU had a sizeable 'carrot' left: its feasibility study of Serbia's preparedness for a Stabilization and Association Agreement (SAA). The study was launched officially in October of 2004 by then EU External Relations Commissioner Chris Patten. However, when the announcement was made, there was no emphasis on the connection between ICTY compliance and a positive assessment. ${ }^{23}$ On January 202005 , Olli Rehn, the EU's new Commissioner for Enlargement, made that condition explicit at a meeting of the European Parliament's Committee on Foreign Affairs. ${ }^{24}$ Rehn advised that Serbia's feasibility study was near completion and that his delegation was due to arrive in Belgrade on January 25. Moreover, Rehn stressed, Serbia had to make serious progress on cooperation with the ICTY because that was a precondition for a positive assessment. $^{25}$ To add further credibility to Rehn's admonishment, EU High Commissioner Javier Solana publicly cancelled his scheduled visit to Belgrade planned for the same day as Rehn's address to the Committee. Solana's key ground for the snub: inadequate cooperation with The Hague. ${ }^{26}$

\footnotetext{
${ }^{23}$ EU External Relations Commissioner, Chris Patten, 'Commissioner Patten announces launch of Feasibility Report on Serbia and Montenegro,' 11 October 2004, IP/04/1202, Brussels, <http//europa.eu.int/comm/external_relations/see/news/2004/ip04_1202.htm> (April 29, 2005).

24 'Sedam dana do odluke,' B92 News, 20 January 2005, <www.b92.net/info/vesti/index.php?yyyy=2005\&mm=01\&dd=20\&nav id=160368\&nav_category=11> (January 21, 2005).

25 Ibid.

26 'Solana ne dolazi u Beograd,' B92 News, 20 January 2005, <www.b92.net/info/vesti/index.php??yyyy=2005\&mm=01\&dd=20\&nav_id=160393\&nav_category=11> (January 21, 2005).
} 
The message from Strasbourg and Brussels on the tie-in between cooperation and feasibility had near instantaneous affect. Upon his arrival in Belgrade on January 25, Rehn received assurances from Kostunica that his government would fulfill its obligations to the Tribunal. Furthermore, Kostunica advised, a number of "voluntary surrenders" were expected shortly. ${ }^{27}$ On January 26, then Deputy Prime Minister Miroljub Labus gave a public interview indicating that the Kostunica's government took Rehn's stipulation very seriously:

"We [the Serbian government] understand this moment not as whether we want to cooperate with The Hague but whether Serbia wants to join the EU. The time has come for us to decide whether or not we are in favour of joining the EU. If we decide in favour, then we know what kind of policy we have to follow regarding cooperation with The Hague, and likewise all other issues.... [...]., ${ }^{, 28}$

Both Kostunica and Labus were not bluffing. No later than January 29, three days after Rehn's visit, General Lazarevic, a high-ranking indictee, announced that he would surrender "voluntarily" to the Tribunal. ${ }^{29}$ In response, and in what should be noted as distinct break from the past practice of issuing hard-and-fast deadlines (e.g. the Serbian elections of 2003), Rehn rewarded the Serbian government with more time: they had until the end of March to achieve "full cooperation." ${ }^{30}$ Kostunica and Labus made expeditious

\footnotetext{
27 'Oli Ren: SCG mora da ucini znacajan korak u sradnji sa Haskim tribunalom,' Danas, 26 January 2005, <www.danas.co.yu/20050126/frontpage1.htm> (January 26, 2005).

28 'Trenutak Odluke?' B92 News, 26 January 2005, <www.b92.net/info/emisije/kaziprst.php?nav_id=160835\&yyyy=2005\&mm=01> (January 26, 2005).

29 'Jedan se predao, ostala jos trojica,' B92 News, 29 January 2005, <www.b92.net/info/vesti/index.php?dd=29\&mm=1\&yyyy=2005> (January 29, 2005).

${ }^{30}$ It is interesting to note that the definition of "full cooperation" has been a contested term throughout the history of ICTY compliance. Regarding the cited deadline see 'EU: Rok do kraja marta,' B92 News, 31 January 2005, <www.b92.net/info/vesti/index.php?yyyy=2005\&mm=01\&dd=31\&nav id=161146> (February 1, 2005).
} 
use of it. Lazarevic's surrender marked the beginning of a wave of "voluntary surrenders," which averaged at times one indictee per week and reached a total of 16 new extraditions by the end of April. Included in this list of extraditions were such highprofile indictees as Generals Lukic (surrendered April 4) ${ }^{31}$ and Pavkovic (surrendered April 25). ${ }^{32}$ While neither General Mladic nor Radovan Karadzic were included as part of this intense move towards cooperation, the EU was nonetheless satisfied. On April 12, the Commission confirmed sufficient progress to open negotiations on a SAA. ${ }^{33}$

\section{c. Cultural Resonance as the (Not-so) 'Silent' Partner: 'It is your Patriotic Duty to Surrender'}

On March 10, 2005, the Serbian daily Blic published an open letter from EU Enlargement Commissioner, Olli Rehn, to the citizens of the Western Balkans. In the letter, Rehn proclaimed the high rate of surrenders to the ICTY from Serbia were proof that membership "conditionality gets results." 34 To a certain extent, he was right. However, his focus on incentives missed out on another equally important dimension in Serbia's move toward full cooperation with the ICTY: the use of justifications to persuade the nation as to the legitimacy of ICTY compliance.

\footnotetext{
31 'Lukic u Hagu,' B92 News, 4 April 2005, <www.b92.net/info/vesti/index.php?dd=48\&mm=4\&yyyy=2005> (April 4, 2005).

32 'Pavkovic stigao u Hag,' B92 News, 25 April 2005, <www.b92.net/info/vesti/index.php?yyyy=2005\&mm=04\&dd=25\&nav_id=167173> (April 25, 2005).

${ }^{33}$ European Commission, 'Serbia and Montenegro: Commission confirms sufficient progress to open negotiations on a Stabilization and Association Agreement,' 12 April 2005, IP/05/421, Brussels, <http://europa.eu.int/comm/external_relations/see/news/2005/ip05_421.htm> (April 15, 2005).

${ }^{34}$ Olli Rehn, 'Zapadni Balkan i napredak ka EU: Zeleno svetlo za SCG u Aprilu,' Blic, 10 March 2005, <www.blic.co.yu/arhiva/2005-03-10/strane/politika.htm> (March 11, 2005).
} 
Entering 2005, the ICTY was as much an affront to Serbian perceptions of "national interest" and patriotism as it had been in prior years. Surveys commissioned in July 2004 by the Federal Ministry of Human and Minority Rights (Serbia and Montenegro) told a familiar story to observers and practitioners of Serbian politics. 76 percent of respondents considered the ICTY to be a "political" rather than a "legal" institution. ${ }^{35} 62$ percent of Serbian citizens did not think that the extraditions of Generals Lazarevic, Lukic, Pavkovic and Djordjevic were in Serbia's "national interest." "36 Therefore, whatever medium to long-run benefits the EU could offer Serbia in exchange for ICTY compliance, Kostunica's government had to deal with the certain and calamitous risk of being labeled "unpatriotic" or working against the "national interest." After all, what made the task of ICTY cooperation so politically distasteful was the fact that most citizens viewed the indictees as military men that simply "did their jobs" on behalf of the nation. $^{37}$ If compliance were to be cast as unpatriotic, this would not only suggest electoral disaster but would also render impotent any public pressure campaign for "voluntary surrenders."

To avoid such a scenario, Kostunica's government chose to play the "patriotic card" before the generals or anybody else could. The scope of the strategy quickly became apparent once General Lazarevic broke the ice and decided to "voluntarily surrender" on

\footnotetext{
${ }^{35}$ See poll conducted by the Strategic Marketing Agency between July 23 and 25, 2004: Ministry of Human and Minority Rights, Serbia and Montenegro, 'Iztrazivanje javnog mnenja o Haskom tribunalu,' (Belgrade: Strategic Marketing Agency, July 2005), <www.humanrights.gov.yu/files/doc/stavovi_prema_ICTY_jul_2004.doc $>$ (February 15, 2005).

${ }^{36}$ Ibid., 9.

${ }^{37}$ Judy Dempsey, 'In Belgrade, unity falls into history,' International Herald Tribune, 25 October 2004, p.1.
} 
January 29. Mihajlo Bakrac, lawyer for General Lazarevic, announced the following on behalf of his client: "General Lazarevic has decided to accept his indictment... as a citizen of this country that is prepared to fulfill his duty.",38 In the days leading to Lazarevic's departure, more such messages followed, framing surrender to the ICTY as a noble act of patriotic sacrifice. On February 3, the day before Lazarevic's transfer to The Hague, the General and the Prime Minister paid a visit to Serbian Patriarch Pavle. In a press release issued by the Serbian Orthodox Church, the General was praised:

"Throughout our history, said the Patriarch, we have examples of honourable officers who courageously represented the interests of the people and defended the truth to the end. The Serbian Orthodox Church respects and holds in the highest regard the decision of general Lazarevic to take this difficult path in the interest of the homeland." 39

Further, that evening and as part of a final goodbye, the Mayor of Nis, Smiljko Kostic, whose party was a member of Serbia's governing coalition, held a cocktail reception in honour of General Lazarevic. In his address to the reception, Kostic paid tribute to the General as a national hero:

"I want to thank you as a great general of the Serbian army for what you have done for the nation now in peace, as you had previously in war. [...] I want to, on behalf of the city and citizens of Nis, wish you a save journey to where, well, fate says you must go, but I believe that we will see each other again one day and that we will likely pass our pensioner days together."40

\footnotetext{
38 'Jedan se predao, ostala jos trojica'’ B92 News, 29 January 2005.

${ }^{39}$ Serbian Orthodox Church, 'Patriarch Pavle Meets with Prime Minister Kostunica and General Lazarevic,' 3 February 2005, <www.spc.org.yu/Vesti-2005/02/01-2-05-e.html\#laz> (February 4, 2005).

40 'Lazarevic stigao u Hag,' B92 News, 3 February 2005, <www.b92.net/info/vesti/index.php?dd=3\&mm=2\&yyyy=2005> (February 3, 2005).
} 
With Lazarevic's surrender and send-off, Kostunica's coalition framed the issue of ICTY cooperation in the Serbian political discourse by constructing a powerful equation linking "voluntary surrender" with Serbian patriotism. This framing of the issue served as a powerful persuasive mechanism (See Risse et al., 1999) to get the rest of the indictees to surrender. It was now difficult for the remaining generals or hard-nationalists, such as the Serbian Radical Party, to monopolize the mantle of Serbian patriotism in an argument against ICTY cooperation: if an indictee loved and cared for his country, then he would not stand in the way of his homeland becoming a member of the European family of nations. This 'patriotic' formula proved remarkably effective, within a matter of months an unprecedented 15 indictees followed Lazarevic voluntarily-more or less-to The Hague without any significant public backlash.

In sum, Olli Rehn was right, conditionality did do its' job. However, what he did not acknowledge was the work that political justification and framing did in the Serbian public sphere, which legitimized the project to the Serbian public. The Kostunica government did not simply seize the abovementioned generals in immediate response to EU incentives. Rather, a delicate combination of public persuasion in the form of issue framing and "voluntary surrenders" was used to ensure that ICTY cooperation remained consistent with prevailing Serbian perceptions of patriotism. In fact, Serbian compliance amounted to a somewhat quizzical formula: military officers indicted by the ICTY for alleged war crimes were voluntarily and ceremoniously transferred to The Hague as national heroes. How this squared with the premise behind ICTY conditionality was certainly a matter for debate. 


\section{d. The Problem of Legitimacy: 'General Mladic, it is our (Patriotic) Duty to Arrest you'}

The normative limits of the 'voluntary surrender' policy and the fact that the Serbian government was reluctant to stretch beyond it soon became apparent however with the case of General Ratko Mladic. At the start of Stabilization and Association negotiations in October 2005, the EU Commission stipulated that further negotiations in the coming year were conditional upon Serbia's continued cooperation with the ICTY. ${ }^{41}$ A key indicator of such cooperation was the extradition of the abovementioned ICTY indictee. Yet, as the weeks and months past, it became increasingly clear that the policy of "voluntary surrender" had reached its end with respect to Mladic. Despite a plethora of media reports and speculation, the aforementioned indictee had not only failed to surrender but there was apparently no knowledge of his whereabouts. ${ }^{42}$ Further still, the Kostunica government was not ready to engage in harsher measures, such as arrest and forcible extradition; notwithstanding that EU membership conditionality was at stake.

The Serbian government's hesitancy was to a considerable extent explainable on pragmatic political grounds. First, while Serbian public opinion had warmed to ICTY cooperation, such approval was largely limited to support for voluntary surrenders as a matter of pragmatic necessity. ${ }^{43}$ Second, Mladic's prolonged flight from authority cast

\footnotetext{
${ }^{41}$ Enlargement Commissioner, Olli Rehn: European Commission (2005) 'Ceremony to open SAA negotiations Federal Palace, Belgrade', <http://www.eudelyug.org/en/news/news/final20051010/final20051010.htm> (October 11, 2005).

42 'Kostunica: Cinimo sve sto mozemo,'B92 News, 24 February 2006, <http://www.b92.net/info/vesti/index.php?dd=24\&mm=2\&yyyy=2006> (July 31, 2006).

43 The earlier-noted survey commissioned in July 2004 by the Federal Ministry of Human and Minority Rights also found that 56 percent of respondents considered voluntary surrender a 'patriotic act'. See <www.humanrights.gov.yu/files/doc/stavovi_prema_ICTY_jul_2004.doc> (February 15, 2005).
} 
him as a folk-hero among many on the Serbian political-right. ${ }^{44}$ The right-wing was no political backwater: polls in early 2006 revealed that the leading party of the right, the Serbian Radical Party, was not only the most popular party in the republic but, further still, it could form the next government. Third, Milosevic's Socialist Party of Serbia, which Kostunica relied on in parliament, declared that it would rethink its support for the government should Mladic be arrested. ${ }^{45}$ Lastly, the anticipated prospect of Montenegrin and possibly Kosovo secession also raised the chances of further nationalist reactions in Serbia and hence added political turbulence for the government.

All told, the above factors likely caused the Kostunica government to question whether it was capable of a forcible but yet political feasible extradition of Mladic. Therefore, despite a number of public admonishments and grants of extension by the EU between February and April of 2006, Belgrade proved incapable-publicly at least_of locating and extraditing the impugned General. ${ }^{46}$ As a consequence, the Commission on May 3 announced the suspension of negotiations with Serbia regarding a SAA. ${ }^{47}$ Further, the EU added, negotiations would remain suspended until such time as Mladic was delivered to The Hague.

\footnotetext{
44 'Mass pro-Mladic rally in Belgrade,' BBC News, 24 February 2006, <http://news.bbc.co.uk/go/pr/fr//2/hi/europe/4749420.stm> (February 24, 2006).

45 'Kostunica nije dao tvrdo obcecanje,' B92 News, 8 May 2006, <http://www.b92.net/info/vesti/index.php?yyyy=2006\&mm=05\&dd=08\&nav_id=196941>(July 30, 2006).

46 'EU: Ili Mladic ili Evropa,' B92 New, 28 February 2006, <http://www.b92.net/info/vesti/index.php?yyyy=2006\&mm=02\&dd=28\&nav_id=189979 > (July 30, 2006).

47 'Ode Evropa, ali ceka na Mladica,' Glas Javnosti, 4 May 2006, <http://archiva.glasjavnosti.co.yu/archiva/2006/05/04/srpski/p06050301.shtml > (July 30, 2006).
} 
Kostunica had now made his second 180 degree turn in relations with the ICTY. One year earlier, his government went from noncompliance to compliance with the extradition of 16 generals in the span of mere months. Now, the government reverted back from compliance to noncompliance because of its failure to deliver Mladic. In both cases, similar incentives were at work and similar commitments were made to European integration and cooperation with the ICTY. However, this time the result was different. Kostunica was constrained by the norms behind his voluntary surrender policy and instability manifested by Montenegrin and Kosovan secessionism. Yet, Mladic's failure to surrender and the EU's subsequent sanctions revealed that the status quo was not enough. Mladic had to go forcibly; but how would the government manage this in light of its previous policy and the above-identified constraints?

In the days that followed the suspension, the Kostunica government indicated it was prepared to take a tougher stand on Mladic. Arrests of those alleged to have sheltered the General soon came. ${ }^{48}$ Police searches publicly intensified. ${ }^{49}$ Further, in July 2006, the government presented to the EU Council of Ministers an 'action plan' for full cooperation with the ICTY; a plan which included the prompt arrest and extradition of Mladic. $^{50}$ The Councils' reaction to the document was so positive that it even debated whether to allow negotiations to continue based on the plan alone; however in the end

\footnotetext{
48،Zavrsena akcija oko Mladiceve kuce,' B92 News, 5 May 2006, <http://www.b92.net/info/vesti/index.php?dd=5\&mm=5\&yyyy=2006> (July 31, 2006).

49 'Potraga za Mladicem u Valjevu,' B92 News, 7 May 2006, <http://www.b92.net/info/vesti/index.php?dd=7\&mm=5\&yyyy=2006> (July 31, 2006).

50 'Vlada usvojila Akcioni plan,' B92 News, 20 July 2006, <http://www.b92.net/info/vesti/index.php?dd=20\&mm=7\&yyyy=2006> (July 31, 2006).
} 
this came to no avail as a promise was merely given that negotiations would restart once Mladic was caught. ${ }^{51}$

Yet, what proved most interesting in this turn affairs was the framing used by the government-yet again - to justify its new arrest and extradition policy to the Serbian public. A new equation was added to the previous frame of "voluntary surrender means Serbian patriot': true patriots do not hold their nation hostage. This frame built upon its predecessor and was the normative pretext for an active campaign of apprehension and extradition. Kostunica's coalition partners made frequent use of this justification in wake of the suspended negotiations. For instance, on May 5, in response to a police raid on Mladic's house, Interior Minister Dragan Jocic exclaimed:

"We are giving everything we have to finish this final task. I have to say that no one has the right to choose himself over his nation, especially when he has a duty to defend his people." 52

Further, following a meeting with EU representatives on May 12, the Serbian Minister for Capital Investment, Velimir Ilic, implored:

"Mladic has to understand the position of his nation, which has a big problem. He has to be selfless, to surrender, go before that court and let his nation go forward. If I were in his position, I wouldn't think a minute. I would come out and say, 'Here I am, please. Just or unjust, I am a victim, do what you want, but let my people go.",

\footnotetext{
51 'Uhapsiti Mladica do septembra,' B92 News, 19 July 2006, $<$ http://www.b92.net/info/vesti/index.php?yyyy=2006\&mm=07\&dd=19\&nav id=205157> (July 19, 2006).

52 'Zavrsena akcija oko Mladiceve kuce,' B92 News, 5 May 2006

53 'I dalje finansijska podrska EU,' B92 News, 12 May 2006, $<$ http://www.b92.net/info/vesti/index.php?dd=12\&mm=5\&yyyy=2006> (July 31, 2006).
} 
Finally, upon a May 13 visit to Moscow, then Foreign Minister Vuk Draskovic declared: "We are now in a tragic situation where instead of the nation arresting Mladic, Mladic has arrested the Serbian nation.",54

At the time of writing this paper, Draskovic's metaphor retains its applicability vis-à-vis Serbia's status on ICTY cooperation, albeit to a lesser extent. General Mladic still remains at large; however the near rise to power of the Serbian Radical Party following the January 2007 parliamentary election prompted the EU to significantly lessen its conditions for the resumption of Stabilization and Association talks. Following the formation of the new Kostunica/Tadic/Dinkic coalition government in mid-May, the European Commission announced the continuation of SAA negotiations on June 13, 2007, revising its key proviso that 'full cooperation' with the ICTY was no longer a prerequisite for continued talks but rather an executed agreement. Yet synchronized with this policy change were two new apprehensions made by the Serbian government: first, on May 31, indictee Zdravko Tolimir was caught at the Serbia/Bosnia border and extradited to The Hague $;^{55}$ followed on June 17 by the apprehension of Vlastimir Djordjevic in the Montenegrin resort town of Budva. ${ }^{56}$

\footnotetext{
54 'Bezbednosne sluzbe stite Mladica,' B92 News, 13 May 2006, $<$ http://www.b92.net/info/vesti/index.php?yyyy=2006\&mm=05\&dd=13\&nav id=197584> (August 1, 2006).

55 "Potvrdjeno hapsenje Tolimira," B92 News, 31 May 2007, <http://www.b92.net/info/vesti/u_fokusu.php?id=7\&start=15\&nav_id=249195> (June 24, 2007).

56 "Reakcije na hapsenje Djordjevica," B92 News, 17 June 2007, http://www.b92.net/info/vesti/u_fokusu.php?id=7\&start=0\&nav_id=251702 (June 17, 2007).
} 
Clearly, the complex history of ICTY compliance in Serbia faces an uncertain end, with key indictees (e.g. Mladic and Karadzic) continuing to elude capture. However, the intent of the above history was not to provide fuel for prognostication and prediction, rather the goal was more basic: to empirically challenge a rationalist and model-driven outlook of political 'reality.' In other words, to demonstrate empirically the distinction between 'modellised' theory and the complexity of political practice, so that we may reflect upon both the nature of the ICTY problem and the problematique of theory as practice in the study of international politics.

In this light, what should be foremost derived from the above historiography is that 'modellised' theory can be fundamentally detached from the actual practice of compliance politics. Compliance can be profoundly messy and non-linear due to an intertwining of material, normative and temporal aspects; which are contrary to 'modellised' representations "of the way things obviously are (Taylor, 1984: 17-26)." Complex cases, such as ICTY compliance, reveal this tension between essentialized theory and practice as they engage not only cost-benefit calculations but also fundamental problems of time and cultural meaning. By putting the particulars of the Kostunica case into focus, therefore, and returning context to the analysis of compliance processes, we can begin to appreciate compliance politics not in terms of stylized 'bargaining' versus 'arguing' schematics but as a delicate political experience profoundly influenced by variable material, normative and temporal aspects. 
Indeed, one could assert, a la Schimmelfennig, Sedelmeier and Kelley, that 'dominant' or 'primary' mechanisms can be ascertained at various instances. In the above case study, this is clearly visible at particular times when a given dimension (e.g. material, normative or temporal) had a parochial-rather than ubiquitous or universal-influence over the sequence of events (see Roberts, 1996: 67). For instance, the Kostunica government's later conversion to a 'voluntary surrender' policy in the spring of 2005 could be argued as 'proof' that Olli Rehn's incentives 'worked'. However, having traced the sequence of events which came before, during and after the Feasibility Study deadline, we can also counter that the material incentives involved were a necessary but not sufficient condition for what transpired (see McIntyre, 1978: 196). The added historical context revealed that Rehn's incentives did not perform as a "lever" would in mechanics, bringing about a particular effect (Ringer, 1989: 157)." Rather, a number of dimensions (material, normative and temporal) had to coincide together.

This distinction, I argue, is an important one for the study compliance influence and practices as it reveals a priori formulations to be profoundly misleading: the experience of compliance politics is not intrinsically linked to sticks, carrots, or any other practical 'hammer'. Rather it is a politics that is inherently practical in the sense that it "deals with doing the right thing at the right time in view of particular historical circumstances (Kratochwil, 2006: 6)." What I have tried to do with this inductive study of the Serbian case is illustrate that such a practical awareness can only come about through a sui generis understanding of historical context of a case-a form of thinking antithetical to monological theory and entrenched models. 


\section{Concluding Remarks - Compliance Politics and the Problem of Theory as Practice}

Imagine for a moment that you are professor of international politics and an eager student asks you a question related to the one addressed here: how do you explain Serbia's inconsistent pattern of compliance with ICTY conditionality? What would you answer? Would you say that compliance politics is based on a cost/benefit calculation, stimulated by the right combination of 'carrots and sticks'? Alternatively, would you say that compliance is foremost about cultural politics and how particular conditions relate to the identity of a target actor? Or, would you assert that theories are indeed pointless and alternatively proffer an exhaustive historical account which traces events leading to various compliance outcomes? If you identified all the above answers as singularly false, and focused instead on the dimensions and processes which might have led to the questioned compliance pattern, then the chances are good that this paper made its intended impression upon your manner of compliance analysis.

In sum, this paper has challenged the tendency to generalize about patterns of compliance that fit neatly within a given rationalist model; while such assumptions may prove helpful in the initial stages of a research design, the inclination often meets frustration when confronted by the actual practice of complex cases such as ICTY compliance in Serbia. Rather than shun the complexity of historical context, it is argued here, we should embrace it within our theoretical and historiographical frameworks; recognizing the inherent multidimensional and diachronic nature of compliance politics. 
Inductive process-tracing of the Serbian case revealed compliance as incommensurate with a model of causal efficiency and linear effectiveness. The compliance process was complicated by the interaction of material incentives, normative concerns and contingent events; factors inherent to the making of compliance outcomes yet something which the rational-consequentialist model 'brackets' away. To many dyed-in-the-wool 'scientists', this bracketing — or 'forgetting' — is entirely unproblematic as the identity of political and social science is firmly tied to a classical perception of scientific inquiry: scholarly investigation and theory is nothing more than a passive recording of an independent and objectified world.

Yet, a more reflexive outlook on the relationship between theory and 'reality', I argue, radically impinges upon that presumption, as the work of theorizing is more closely associated with the construction of social meaning, influencing the very actions which form political and social practice. From this perspective, the 'modellised' status quo becomes more than a 'scientific' adventure into the abstract, as the cognitive pretense to represent "the way things obviously are" links 'the model' to our exercise of political judgment: its claim 'to know' becomes the foundation for advising 'what to do' and when. Simply put, as theory produces reality, theoreticians becomes the artificers of 'reality,' and flowing from this ascription come important questions of responsibility and ethics on the manner in which we represent 'the political.' The hope of the author is that the metatheoretical and historiographical orientation of the paper has developed, to some extent, this sorely needed practical awareness within the field of compliance theory. 


\section{Bibliography}

Abbott, Andrew (1983) 'Sequences of Social Events: Concepts and Methods for the Analysis of Order in Social Processes', Historical Methods 16(4): 129-147.

Abbott, Andrew (1988) 'Transcending General Linear Reality', Sociological Theory 6(2): 169-186.

Barnett, Michael (1999) 'Culture, Strategy and Foreign Policy Change: Israel's Road to Oslo', European Journal of International Relations 5(1): 5-36.

Beyerchen, Alan (1992/1993) 'Clausewitz, Nonlinearity, and the Unpredictability of War', International Security 17(3): 59-90.

Bourdieu, Pierre (2005) Outline of a Theory of Practice. Cambridge: Cambridge University Press.

Carr, E.H. (1961) What is History? London: McMillan.

Checkel, Jeffrey T. (2000) 'Compliance and Conditionality', ARENA Working Paper WP 00/18. Swww.arena.uio.no/publications/wp00_18.htm> (December 26, 2004) Oslo: ARENA/University of Oslo.

Checkel, Jeffrey T. (2001) 'Why Comply? Social Learning and European Identity Change', International Organization 55(3): 553-588.

Checkel, Jeffrey T. (2005) 'International Institutions and Socialization in Europe: Introduction and Framework', International Organization 59: 801-826.

Davis, James W. (2005) Terms of Inquiry: On the Theory and Practice of Political Science. Baltimore: John Hopkins University Press.

George, Alexander and Andrew Bennett (2005) Case Studies and Theory Development in the Social Sciences. Cambridge: Belfer Center for Social Science and International Affairs.

Guzzini, Stefano (2000) 'A Reconstruction of Constructivism in International Relations', European Journal of International Relations 6(2): 147-182.

Hobson, John M. (2002) 'What's at stake in 'bringing historical sociology back in international relations?' Transcending 'chronofetishism' and 'tempocentrism' in international relations', in Stephen Hobden and John M. Hobson (eds) Historical Sociology of International Relations. pp. 3-41. Cambridge: Cambridge University Press. 
Hughes, James and Gwendolyn Sasse (2003) 'Monitoring the Monitors: EU Enlargement Conditionality and Minority Protection in the CEECs', Journal of Ethnopolitics and Minority Issues in Europe, 1: 1-35.

Ikenberry, G. John and Charles A. Kupchan (1990) 'Socialization and Hegemonic Power', International Organization 44(3): 283-315.

Johnston, Alastair Iain (2001) 'Treating International Institutions as Social Environments', International Studies Quarterly 45: 487-515.

Kelley, Judith (2004) 'International Actors on the Domestic Scene: Membership Conditionality and Socialization by International Institutions', International Organization 58: 425-457.

Kelley, Judith (2005) Ethnic Politics in Europe: The Power of Norms and Incentives. Oxford: Princeton University Press.

Kratochwil, Friedrich (2000) 'Constructing a New Orthodoxy? Wendt's 'Social Theory of International Politics' and the Constructivist Challenge', Millennium: Journal of International Studies 29(1): 73-101.

Kratochwil, Friedrich (2006) 'History, Action and Identity: Revisiting the 'Second' Great Debate and Assessing its Importance for Social Theory', European Journal of International Relations 12(1): 5-29.

Kratochwil, Friedrich (2007) 'Of false promises and good bets: a plea for a pragmatic approach to theory building (the Tartu lecture)', Journal of International Relations and Development 10(1)(2007):1-15.

Lebow, Richard Ned (2007) 'Social Science as an Ethical Practice', Journal of International Relations and Development 10(1)(2007): 16-24.

Long, William J. (1996) 'Trade and Technology Incentives and Bilateral Cooperation', International Studies Quarterly 40: 77-106.

Lustick, Ian S. (1996) 'History, Historiography, and Political Science: Multiple Historical Records and the Problem of Selection Bias', American Political Science Review 90(3): 605-618.

MacIntyre, Alasdair (1978) Against the Self-Images of the Age: Essays on Ideology and Philosophy. South Bend, IN: University of Notre Dame Press.

Manners, Ian (2002), “Normative Power Europe: A Contradiction in Terms?”, Journal of Common Market Studies 40(2): 245-58.

March, James G., and Johan P. Olsen (1998) 'The Institutional Dynamics of International Political Orders', International Organization 52(4): 943-69. 
March, James G., and Johan P. Olsen (2005) 'Elaborating the 'New Institutionalism', ARENA Working Paper WP 11, March 2005 <www.arena.uio.no> Oslo: ARENA/University of Oslo.

Pierson, Paul (2004) Politics in Time: History, Institutions, and Social Analysis. Princeton: Princeton University Press.

Pridham, Geoffrey (2002) 'EU Enlargement and Consolidating Democracy in PostCommunist States-Formality and Reality', Journal of Common Market Studies 40(3): 953-73.

Reus-Smit, Christian (2002), 'The idea of history and history with ideas', in Stephen Hobden and John M. Hobson (eds) Historical Sociology of International Relations. pp. 120-140. Cambridge: Cambridge University Press.

Ringer, Fritz K. (1989) 'Causal Analysis in Historical Reasoning', History and Theory 28(2): 153-172.

Risse, Thomas, Stephen C. Ropp, and Kathryn Sikkink (eds) (1999) The Power of Human Rights: International Norms and Domestic Change. Cambridge: Cambridge University Press.

Risse, Thomas, Daniela Engelmann-Martin, Hans-Joachim Knopf and Klaus Roscher (1999) 'To Euro or Not to Euro? The EMU and Identity Politics in the European Union', European Journal of International Relations 5(2): 147-187.

Roberts, Clayton (1996) The Logic of Historical Explanation. University Park: The Pennsylvania State University Press.

Risse, Thomas (2000) 'Let's Argue! Communicative Action in World Politics', International Organization 54(1): 1-39.

Ruggie, John Gerrard (1998a) 'What Makes the World Hang Together? NeoUtilitarianism and the Social Constructivist Challenge', International Organization 52(4): 855-885.

Sahlins, Marshall (1976) Culture and Practical Reasoning. Chicago: University of Chicago Press.

Schimmelfennig, Frank, Stefan Engert and Heiko Knobel (2003) 'Costs, Commitment and Compliance: The Impact of EU Democratic Conditionality on Latvia, Slovakia and Turkey', Journal of Common Market Studies 41(3): 495-518. 
Schimmelfennig, Frank and Ulrich Sedelmeier (2004) 'Governance by Conditionality: EU rule transfer to the candidate countries of Central and Eastern Europe', Journal of European Public Policy 11(4): 669-687.

Schimmelfennig, Frank and Ulrich Sedelmeier (eds) (2005) The Europeanization of Central and Eastern Europe. Ithaca: Cornell University Press.

Schimmelfennig, Frank (2005) 'Strategic Calculation and International Socialization: Membership Incentives, Party Constellations, and Sustained Compliance in Central and Eastern Europe', International Organization 59: 827-860.

Sewell, William H. Jr. (1996) 'Three Temporalities: Toward an Eventful Sociology', in Terrence J. McDonald (ed) The Historic Turn in the Human Sciences. pp. 245280. Ann Arbor: University of Michigan Press.

Sommers, Margaret (1996) 'Where is Sociology after the Historic Turn? Knowledge Cultures, Narrativity, and Historical Epistemologies', in Terrence J. McDonald (ed) The Historic Turn in the Human Sciences. 52-89. Ann Arbor: University of Michigan Press.

Stewart, Ian (1997) Does God Play Dice? The New Mathematics of Chaos. London: Penguin Books.

Taylor, Charles (1984) 'Philosophy and its history', in Richard Rorty, J.B. Schneeewind and Quentin Skinner (eds) Philosophy in History. pp.17-39. Cambridge: Cambridge University Press.

Walker, R.B.J. (1989) 'History and Structure in the Theory of International Relations', Millennium: Journal of International Studies 18(2): 163-183.

Watts, Barry D. (1997/98) 'Ignoring Reality: Problems of Theory and Evidence in Security Studies', Security Studies 7(2): 115-171.

Weber, Max (1948) eds. H.H. Gerth and C. Wright Mills From Max Weber. London: Routledge \& Kegan Paul.

Wiener, Antje (2004) 'Contested Compliance: Interventions on the Normative Structure of World Politics', European Journal of International Relations 10(2): 189-234.

Wendt, Alexander (1999) Social Theory of International Politics. Cambridge: Cambridge University Press.

\section{Interviews and Speeches}

Labus, Miroljub, Deputy Prime Minister of Serbia. 'Trenutak Odluke?' Interview by Ivana Stevanovic (Belgrade, 26 January 2005) B92 News 
www.b92.net/info/emisije/kaziprst.php?nav_id=160835\&yyyy $=2005 \& \mathrm{~mm}=01$

(January 26, 2005).

Vejvoda, Ivan, Director of the Balkan Trust for Democracy, Former Foreign Policy Advisor to Former Serbian Prime Ministers Zoran Djindjic and Zoran Zivkovic. Interview by author, 25 April 2005, Belgrade, Serbia and Montenegro.

Speech by Vuk Draskovic, Foreign Minister of Serbia and Montenegro. In Serbian, given at the Embassy of Serbia and Montenegro in Budapest, Hungary, 20 January 2005.

Zivkovic, Zoran, Former Prime Minister of Serbia. Interview by author, 20 April 2005, Nis, Serbia and Montenegro.

\section{Newswire and Newspaper Sources}

Associated Press. 15 March 2003.

B92 News (Belgrade). 20 October-28 December 2003; 21 February-9 December 2004; 20 January-April 2005; February-August 2006; May-June 2007.

Blic (Belgrade). 10 March 2005

Danas (Belgrade). 26 January 2005.

International Herald Tribune (Paris). 25 October 2004.

New York Times. 16 March 2003.

Republika (Podgorica). 16 October 2004.

Reuters. 22 October 2003; and 12 April 2005.

\section{Press Releases and Manifestos}

European Commission. Press Release. "Commissioner Patten announces launch of Feasibility Report on Serbia and Montenegro." IP/04/1202, Brussels. (11 October 2004):

<http//europa.eu.int/comm/external_relations/see/news/2004/ip04_1202.htm> (April 29, 2005).

European Commission. Press Release. "Serbia and Montenegro: Commission confirms sufficient progress to open negotiations on a Stabilization and Association Agreement" IP/05/421, Brussels. (12 April 2005): 
〈http://europa.eu.int/comm/external_relations/see/news/2005/ip05_421.htm> (April 15, 2005).

Serbian Orthodox Church. Press Release. "Patriarch Pavle Meets with Prime Minister Kostunica and General Lazarevic." (3 February 2005) <www.spc.org.yu/Vesti2005/02/01-2-05-e.html\#laz> (February 4, 2005).

Srpska Radikalna Stranka. "Program Srpske Radikalne Stranke." Velika Srbija. Belgrade: Serbian Radical Party, December 2003. <www.srs.org.yu/onama/program.php?izbor=onama $>$.

\section{Public Opinion Research}

Centar za politikoloska istrazivanja i javno mneje, Institut Drustvenih Nauka. Stavovi Gradjana o Medunarodnoj Zajednici i Odnosima Srbije i Crne Gore Krajem 2004. Godine. Belgrade: Centar za politikoloska istrazivanja i javno mneje, Institut Drustvenih Nauka, 2005. <www.cpijm.org.yu/scharts/Izvestaj1.pdf> (February 11, 2005).

Ministry of Human and Minority Rights, Serbia and Montenegro. "Iztrazivanje javnog mnenja o Haskom tribunalu." Belgrade: Strategic Marketing Agency, July 2005). <www.humanrights.gov.yu/files/doc/stavovi_prema_ICTY_jul_2004.doc> (February 15, 2005). 